\title{
Leaf and sepal colleters in Calolisianthus speciosus Gilg (Gentianaceae): a morphoanatomical comparative analysis and mechanisms of exudation
}

\author{
Analu Zanotti ${ }^{1}$, , Valéria Ferreira Fernandes $^{2}$ (D), Aristéa Alves Azevedo ${ }^{1}$ (i) and Renata Maria Strozi Alves Meira ${ }^{1 *}$ (i)
}

Received: September 18, 2020

Accepted: November 22, 2020

\begin{abstract}
Calolisianthus speciosus, an endemic species of cerrado and campos rupestres in Brazil, bears colleters in both the leaf base and sepal. These colleters (leaf and sepal) were anatomically compared to identify differences in their structure and secretion mechanism. Samples of sepals and leaves in different development stages were collected and processed according to standard methodologies for anatomical and ultrastructural studies. Sepal and leaf colleters were anatomically similar, being non-vascularized, sessile or short-stalked and composed of a multicellular secretory head with large intercellular spaces where secretion, with a predominance of protein and polysaccharides, is accumulated. The secretory cells have thin walls, dense cytoplasm with granular endoplasmic reticulum, numerous dictyosomes and mitochondria. The ultrastructural characters are in agreement with the production of mucilaginous/protein secretion. The large secretion-filled vacuole merges with the plasma membrane releasing its contents to the periplasmic space where it remains until release outside of the cell wall, where it is accumulated in intercellular spaces formed by schizogeny. This accumulation generates pressure that promotes the passage of secretion through the external wall and the cuticle of superficial secretory cells of the head of the colleter.
\end{abstract}

Keywords: histochemistry, mucilage, protein content, secretory structures, ultrastructural analysis

\section{Introduction}

Calolisianthus speciosus belongs to the family Gentianaceae, in which the presence of colleters on the adaxial face of both leaves and sepals is considered a common feature (Struwe et al. 2002). Colleters have been previously described anatomically for leaves and sepals of Gentiana (11 species), Gentianella campestris, G. ciliata, Comastoma tenellum, and Swertia perennis, of the temperate region (Renobales et al. 2001), and for leaves of C. speciosus,
C. pendulus, C. amplissimus (Delgado 2008), C. pedunculatus (Dalvi et al. 2020), Macrocarpea obtustifolia (Dalvi et al. 2014a), Curtia (seven species), and Hockinia montana (Dalvi et al. 2014b) of the tropical region. Calolisianthus pedunculatus is the only species of Gentianaceae from the tropical region for which sepal colleters have been anatomically described (Dalvi et al. 2020).

Colleters are secretory structures usually located on the adaxial surface of vegetative (leaves and stipules) and reproductive (bracts and sepals) organs and exudate viscous substances that lubricate young and developing

1 Pós-graduação em Botânica, Departamento de Biologia Vegetal, Universidade Federal de Viçosa, 36570-000, Viçosa, MG, Brazil

2 Departamento de Ciências Biológicas, Universidade Estadual de Santa Cruz, 45662-900, Ilhéus, BA, Brazil

* Corresponding autor: rmeira@ufv.br 
organs, prevent desiccation and promote protection against phytophages and microorganisms (Fahn 1979; Thomas 1991; Mayer et al. 2013). Antifungal activity was reported for secretions produced by colleters of some species of the subfamily Asclepiadoideae (Ribeiro et al. 2017) and the family Rubiaceae (Miguel et al. 2006). In dry environments, colleter exudates reduce water loss by young organs (Mayer et al. 2013). Thus, colleters can provide selective advantages in evolutionary events and may represent an important strategy for $C$. speciosus, an herbaceous species from Brazilian cerrado and campos rupestres (Calió 2009; Calió et al. 2017). Therefore, understanding mechanisms of secretory exudation in this species is an important model for tropical Gentianaceae.

Herbaceous plants that occur in cerrado and campos rupestres are subject to long periods of drought due to the xeric environmental conditions (Ribeiro et al. 2008). Features, such as the presence of colleters, may contribute to protecting young organs of individuals of these species against water loss. However, the occurrence of colleters in savanna environments has been reported for only a few families, such as Apocynaceae (Appezzato-da-Gloria \& Estelita 2000), Caryocaraceae (Paiva \& Machado 2006a), Fabaceae, (Paiva \& Machado 2006b), Celastraceae (Mercadante-Simões \& Paiva 2013), Gentianaceae (Delgado 2008; Delgado et al. 2011), Salicaceae (Fernandes et al. 2017; Faria et al. 2019) and Rubiaceae (Tresmondi et al. 2015; 2017). This, however, likely reflects the scarcity of detailed morphological studies of secretory structures in cerrado and campos rupestres.

Anatomically, the most common form of colleter is the standard type, which consists of a non-secretory parenchyma axis covered by a palisade secretory epidermis, which bears a thin cuticle (Thomas 1991). In general, secretion accumulates in the periplasmic space and, subsequently, in intercellular spaces (Fernandes et al. 2017) until exuded through the external wall to the outside of the superficial cells (Simões \& Kinoshita 2002; Silva et al. 2012; Martins 2012; Paiva 2016; Fernandes et al. 2017). Leaf and sepal colleters for most species of Gentianaceae for which they have been studies are non-vascularized, sessile or short pedunculated and formed by a multicellular secretory head of isodiametric vacuolated cells with thin walls. The superficial cells are joined by the cuticle, while the internal cells are widely separated from each other by large intercellular spaces where secretion is accumulated (Renobales et al. 2001; Delgado et al. 2011; Dalvi et al. 2014b). Macrocarpaea obtusifolia is the only species of the family Gentianaceae known to date to have standard colleters (Dalvi et al. 2014a).

Mucilaginous or mixed secretion composed of hydrophilic and lipophilic compounds are produced by colleters, which become active in meristems and remain so until complete differentiation of the organ, followed by, in general, subsequent senesce (Paiva 2009). Mucilage and extracellular protein cross the plasma membrane by exocytosis, following their synthesis by the secretory pathway with cooperation between the granular endoplasmic reticulum (GER) and dictyosomes. These organelles are responsible for transforming mono- and disaccharides into polysaccharides, as well transforming and targeting proteins (Lüttge \& Schnepf 1976; Buchanan et al. 2015). Leucoplasts are considered secretion sites of lipid compounds (lipophilic) in colleters (Huang et al. 2008), although they have also been identified as secretion sites of phenolic compounds (Brillouet et al. 2013). A prominent nucleus immersed in dense cytoplasm with numerous small vacuoles are common in the secretory cells of colleters (Paiva \& Machado 2006b; Fernandes et al. 2017; Almeida \& Paiva 2019). Exudation in colleters can occur by pores, cuticle rupture, cuticle permeability or cuticle channels (Paiva \& Machado 2006b; Dalvi et al. 2014a; Miguel et al. 2017; Fernandes et al. 2017; Pinheiro et al. 2019). However, the mechanisms of secretion and exudation remain to be elucidated for colleters of species of Gentianaceae.

This study aims to compare leaf and sepal colleters of C. speciosus and elucidate their mechanism(s) of secretion and exudation.

\section{Materials and methods}

Samples of leaves (from the first to the third node toward the base) and sepals (from floral buds and flowers in anthesis) of three specimens of Calolisianthus speciosus Gilg were collected in campos rupestres of Serra de Ouro Branco State Park, Ouro Branco, Minas Gerais, Brazil (20³0'115.7' to $20^{\circ} 30^{\prime} 12.9^{\prime \prime}$ S; $43^{\circ} 38^{\prime} 29.5^{\prime \prime}$ to $43^{\circ} 38^{\prime} 43.1^{\prime \prime}$ W). Samples were fixed in the field for analysis by light and scanning electron microscopy. Voucher material was deposited in herbarium VIC of Universidade Federal de Viçosa (UFV) under number VIC 49368 (herbaria acronym according to Thiers, continuously updated).

Samples of both leaves and sepals collected in the field and fixed in neutral buffered formalin (NBF; Lillie 1965) were used for anatomical description and histochemical analysis. These samples were dehydrated in an ethanol series, included in methacrylate resin (Historesina Leica Microsystems Nussloch GmbH, Heidelberg, Germany) and transversally and longitudinally sectioned at $5 \mu \mathrm{m}$ thickness using an automatic rotary microtome (model RM2155, Leica Microsystems Inc., Deerfield, USA). The sections were stained with toluidine blue $\mathrm{pH} 4.7$ (O'Brien et al. 1964) for anatomical description. Some of these sections were submitted to histochemical tests for the detection of protein with xylidine ponceau (O'Brien \& McCully 1981) and coomassie blue (Fisher 1968); total polysaccharides with periodic acid-Schiff reagent (PAS; McManus 1948), starch with lugol reagent (Johansen 1940) and pectins/ mucilage with ruthenium red (Johansen 1940). The slides were mounted with synthetic resin (Permount, Fisher 
Scientific, Fair Lawn, NJ). Transverse sections were also obtained with a table microtome (model LPC; Rolemberg and Bhering Trade and Binding LTDA, Belo Horizonte, Brazil) and used for the detection of lipids with Sudan black B (Pearse 1972) and Sudan red (Johansen 1940); and phenolic compounds with ferric chloride (Johansen 1940). Control procedures were carried out simultaneously, as required for each test, with all slides being mounted with glycerinated gelatin.

Observations and photographic documentation were performed with a light microscope (AX70TRF, Olympus Optical, Japan) equipped with an image capture system (Ax Cam, Zeiss, Germany). The terminology for colleter morphology follows González (1998).

Samples for micromorphological analysis, (leaf base and sepals) were fixed in FAA (formaldehyde, glacial acetic acid, $50 \%$ ethanol at 1:1:18) dehydrated in an ethanol series and critical-point-dried (model CPD 030 Bal-Tec, Balzers, Liechtenstein). They were then mounted on stubs with double-sided adhesive tape and sputter-coated with gold (model SCA 010, Bal-Tec, Balzers, Liechtenstein). Observations and photographic recordings were carried out using a model LEO 1430 VP scanning electron microscope (Zeiss, Cambridge, England), at Núcleo de Microscopia e Microanálise (NMM-UFV).

Ultrastructural analyses were performed with sepal colleters. Twelve hours after fixation in $2.5 \%$ glutaraldehyde in $0.1 \mathrm{M}$ sodium cacodylate buffer $(\mathrm{pH} 7.2)$ in the field, the samples were rinsed in the same buffer and postfixed in $1 \%$ osmium tetroxide in $0.1 \mathrm{M}$ sodium cacodylate buffer for $2 \mathrm{~h}$ at room temperature and rinsed in the same buffer. After dehydration in an acetone series, the samples were embedded in low-viscosity acrylic resin (LR White). Sections of 50-60 nm thickness were obtained using an ultramicrotome (Leica EM UC 6; Vienna, Austria) at Centro de Microscopia Eletrônica of Universidade Estadual de Santa Cruz. These sections were collected on copper grids and contrasted with $5 \%$ uranyl acetate aqueous solution and lead citrate (Reynolds 1963). Images were obtained using a Zeiss EM 109 transmission electron microscope (Carl Zeiss Microscopy, Jena, Germany) at $80 \mathrm{kV}$ at NMM/UFV.

\section{Results}

In Figure 1 colleters were found in apical meristems (Fig. 1A) and floral buds (Fig. 1B), on the adaxial surface of the petiole base (Fig. 1C, E) and on the adaxial surface of the sepal base (Fig. 1B, D, F-G). Sepal and leaf colleters are anatomically similar to one another, being sessile or short stalked (Fig. 1) and become active early while still in apical meristems (Fig. 1A) and floral buds (Fig. 1B). Young and differentiated colleters occur in these regions, which originated by protodermal activity (Fig. 1B). During cellular expansion of the secretory head, large intercellular spaces are formed by schizogenesis in the central portion of the mass of secretory cells (Fig. 1C-D). The cuticle keeps the superficial secretory cells adhered to each other. When the secretory phase begins, secretion is accumulated into the intercellular spaces until it is released to the outside of the colleter (Fig. 1A-D, F). Basal and stalk cells of the colleters are isodiametric, vacuolated and thin-walled (Fig 1C-D), while the secretory head is formed by a multicellular mass with large intercellular spaces, where secretion is accumulated (Fig. 1AD). The superficial cells of the secretory head are arranged in a continuous layer, covered by a thin cuticle (Fig. 1C-D). The leaf and sepal colleters are of the lachrymiform type (Fig. 1) and may be bifurcated (1G). The cuticle at the top of secretory head can appear slightly distended (Fig. 1F) while secretion can be observed outside (Fig. 1A-D, F).

Proteins were detected in the cytoplasm of secretory head cells by xylidine ponceau (Tab. 1, Fig. 2A) and coomassie blue (Tab. 1, Fig. 2B) tests. Strong reaction to PAS demonstrated the presence of polysaccharides in the secretory head cells (in the cytoplasm) and in intercellular spaces, as well outside of the secretory head (Tab. 1, Fig. 2C). Lugol reagent detected starch only inside of the secretory cells of leaf colleters (Tab. 1, Fig. 2D). Only the secretory cells of sepal colleters showed positive reactions for pectins/ mucilage (Tab. 1, Fig. 2E) and phenolic compounds (Tab. 1, Fig. 2F). Both sepal and leaf colleters tested negative for lipid compounds (Tab. 1).

Prior to anthesis, the secretory head cells possess thin walls (Fig. 3), dense cytoplasm with small vacuoles and enlarged conspicuous nuclei with decondensed chromatin

Table 1. Results of histochemical tests performed on leaf and sepal colleters of Calolisianthus speciosus. + (positive reaction); - (negative reaction).

\begin{tabular}{|c|c|c|c|c|}
\hline \multirow{2}{*}{\multicolumn{2}{|c|}{ Metabolic group }} & \multirow{2}{*}{ Reagent } & \multicolumn{2}{|c|}{ Results } \\
\hline & & & Sepal & Leaf \\
\hline Carbohydrates & $\begin{array}{c}\text { Neutral polysaccharides } \\
\text { Starch } \\
\text { Pectins }\end{array}$ & $\begin{array}{c}\text { PAS (periodic acid/Schiff reagent) } \\
\text { Lugol } \\
\text { Ruthenium red }\end{array}$ & $\begin{array}{l}+ \\
- \\
+\end{array}$ & $\begin{array}{l}+ \\
+ \\
-\end{array}$ \\
\hline Proteins & $\begin{array}{l}\text { Xylidine Ponceau } \\
\text { Coomassie blue }\end{array}$ & $\begin{array}{l}+ \\
+\end{array}$ & $\begin{array}{l}+ \\
+\end{array}$ & \\
\hline General lipids & $\begin{array}{c}\text { Sudan IV } \\
\text { Sudan Black B }\end{array}$ & - & $\begin{array}{l}- \\
-\end{array}$ & \\
\hline Phenolic compounds & Ferric chloride & + & - & \\
\hline
\end{tabular}


(Fig. 3A). Plasmodesmata connecting adjacent cells are also present. Many dictyosomes associated with GER and small vesicles between the trans-face Golgi are evident (Fig. 3B). Mitochondria (Fig. 3C) and ameboid-shaped leucoplasts containing electron-dense droplets (Fig. 3D) placed near the plasma membrane were also observed. Many small vacuoles were observed near GER (Fig. 3C), which may fuse together producing larger vacuoles (Fig. 3E). A large vacuole filled
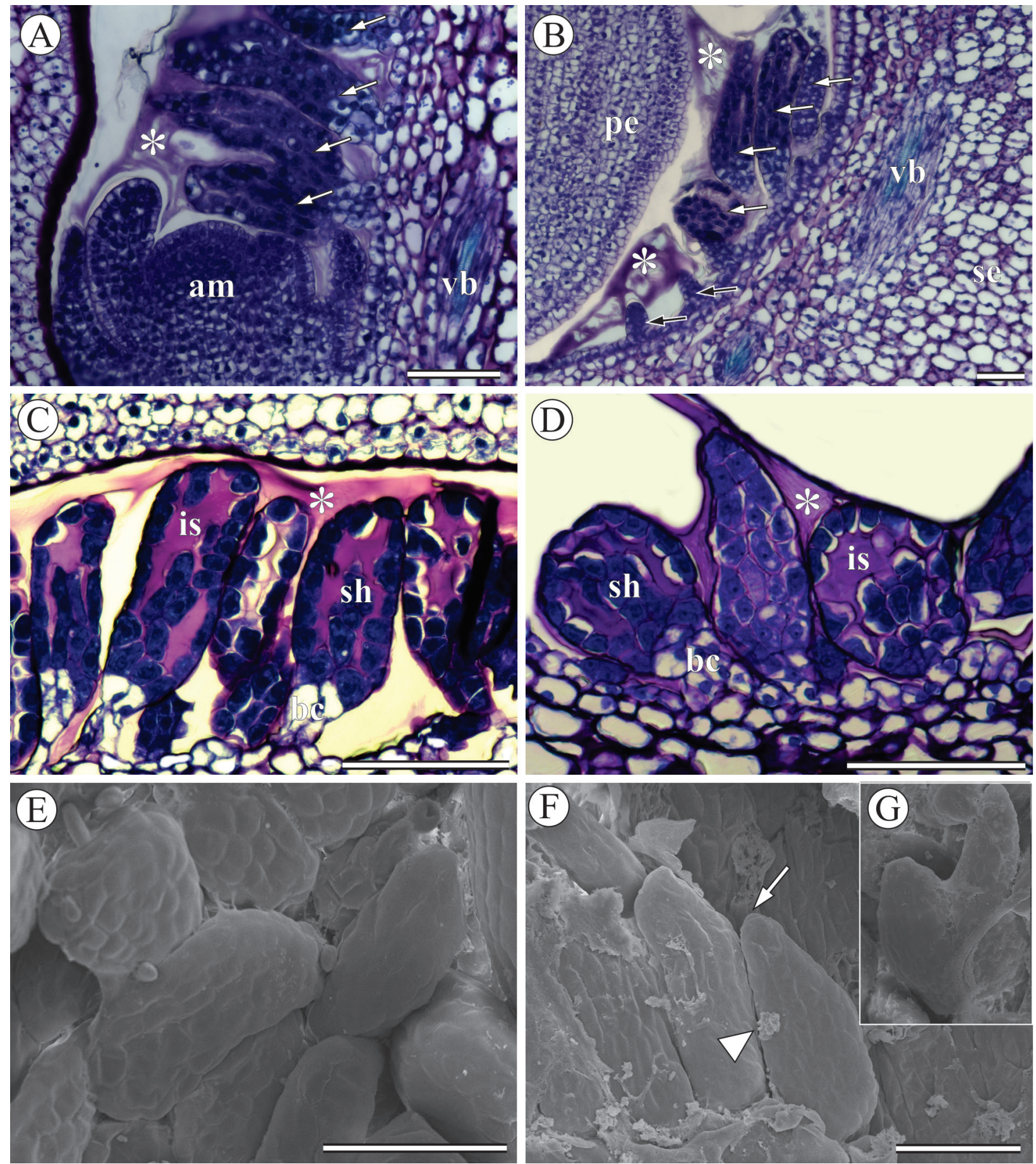

Figure 1. Morphoanatomy of apical meristem (A), sepal (B, D, F-G), and leaf (C, E) colleters of Calolisianthus speciosus. Longitudinal sections stained with toluidine blue under light microscopy (A-D) and under SEM (E-G). A-B: Colleters (white arrows) secreting mucilaginous substances (asterisk) and colleters undergoing differentiation from protoderm (black arrows). C-D: Sessile and shortstalked colleters composed of basal cells and a multicellular secretory head, the cells of which present dense cytoplasm, a relatively large nucleus and secretion in intercellular spaces and outside (asterisk) covering all colleters. E: Leaf colleters. F-G: Sepal colleters. Notice the slightly distended cuticle (arrow) and secretion on the outer surface (arrowhead). G: Detail of a bifurcated colleter. apical meristem (am), basal cells (bc), intercellular space (is), petal (pe), sepal (se), secretory head (sh), vascular bundle (vb). Bars=100 $\mu \mathrm{m}$. 
with granular material was observed near or merged to the plasma membrane (Fig. 3E, F), while the same material was observed in the periplasmatic space (Fig. 3A, D-F). Ingrowth of the plasma membrane and early endosomes were also noted, which maintain the plasma membrane (Fig. 3E, F).
In the cytoplasm (Fig. 4), small vesicles are associated with the trans-Golgi network (TGN) (Fig. 4A) and granular material and myelin figures are inside both the vacuole and endosomes formed during the secretory process (Fig. 4A). The wall between adjacent cells of the central region of the
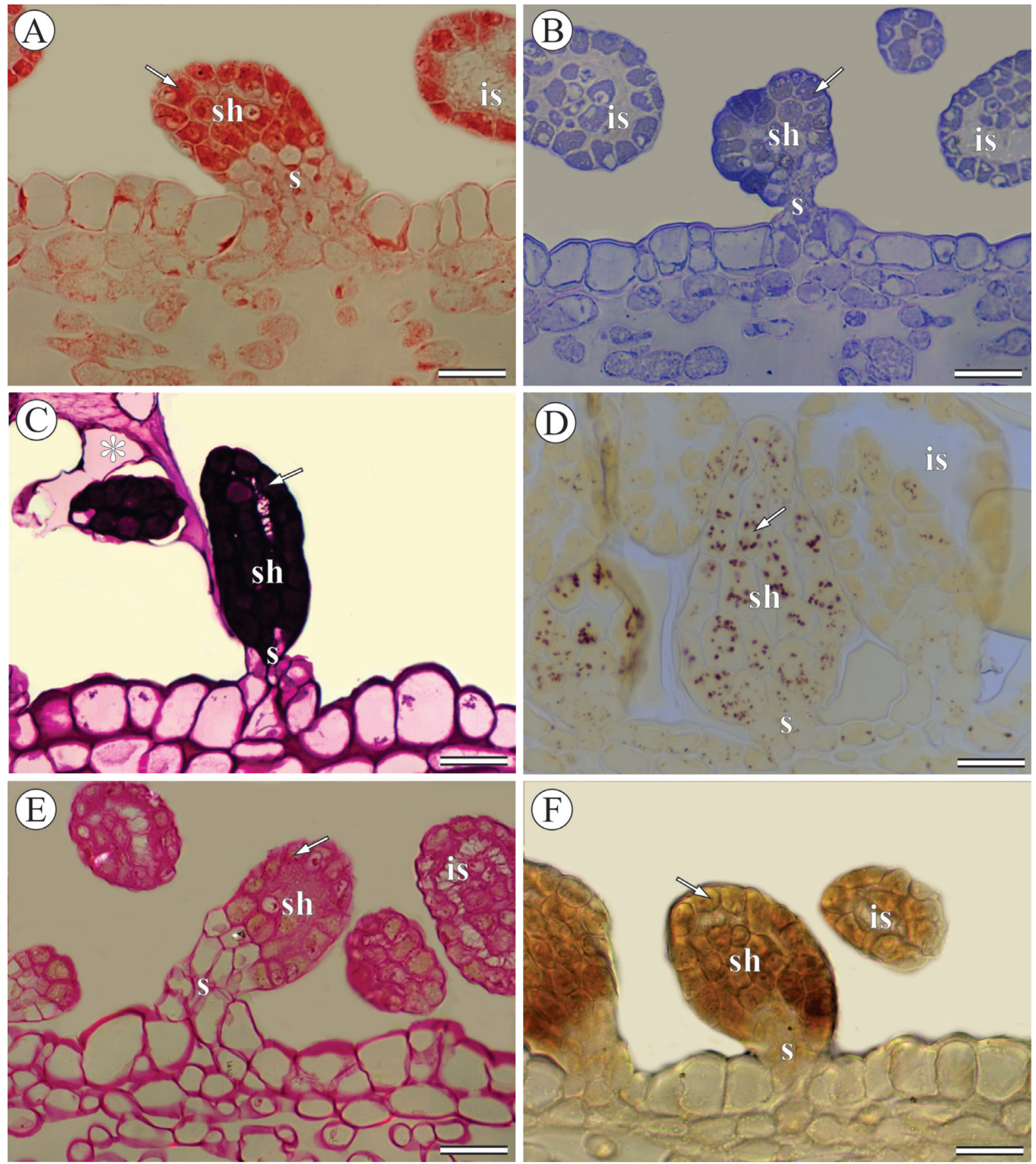

Figure 2. Positive reactions to histochemical tests performed with sepal (A-C, E-F) and leaf (D) colleters of Calolisianthus speciosus. A-B: Proteins in the cytoplasm of secretory head cells, detected by xylidine ponceau (A) and coomassie blue (B). C: Polysaccharides throughout the secretory head (cells and intercellular spaces) and external (asterisk), detected by periodic acid/Schiff reagent (PAS). D: Starch in the cytoplasm of the secretory head cells evidenced by lugol reagent. E: Pectins/mucilage in the intercellular spaces and secretory head cells revealed by ruthenium red. F: Phenolic compounds in the secretory head evidenced by ferric chloride. intercellular space (is), stalk (s), secretory head (sh). Bars $=30 \mu \mathrm{m}$. 
secretory head is thin and primary. Cell separation occurs due to degradation of the middle lamella, giving rise to intercellular spaces (Fig. 4B). No evidence of cellular lysis was observed.
Granules and homogenous material, similar to that inside the vacuoles, were also observed in the intercellular spaces (Fig. 3A, 4A, B). The main difference in the secretory cells that cover the secretory head is the presence of the

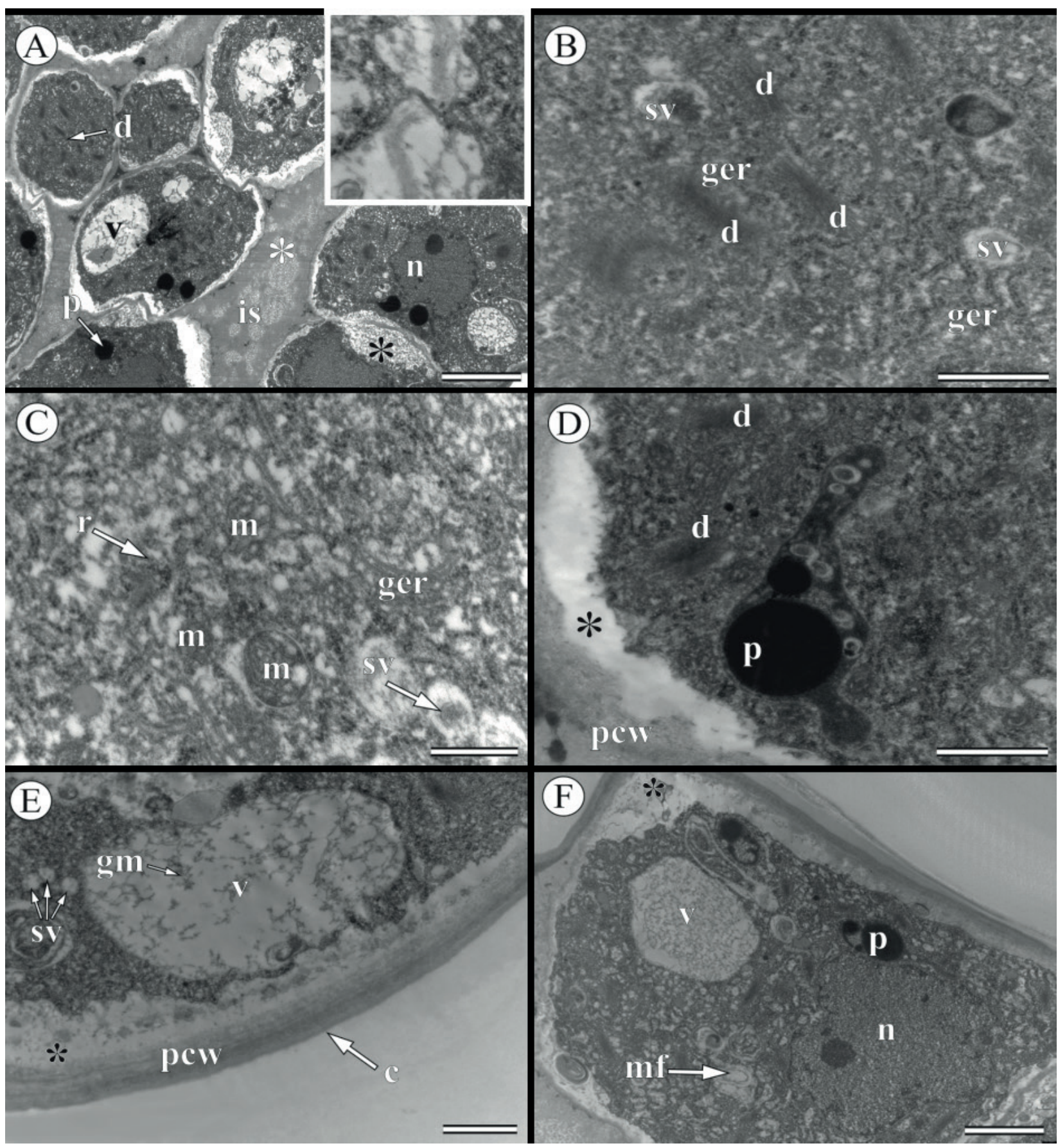

Figure 3. Ultrastructure of sepal colleters of Calolisianthus speciosus during the secretory phase (floral buds prior to anthesis). A: Secretory head cells with dense cytoplasm, conspicuous nucleus, many dictyosomes and small vacuoles, and thin walls; note the periplasmic spaces (black asterisk) and the intercellular spaces (white asterisk) containing secretion. Plasmodesmata connecting cells (detail) B: Detail of cytoplasm showing numerous dictyosomes associated with GER. C: Detail of cytoplasm with many mitochondria, GER and some vesicles. D: Substances accumulated in periplasmic space (black asterisk) and a leucoplast with ameboid shape and electron-dense content. E: Larger vacuoles resulting from the fusion of small vacuoles with granular material inside. F: Myelin figures were inside a vacuole. cuticle (c), dictyosome (d), granular material (gm), granular endoplasmic reticulum (ger), intercellular space (is), mitochondria (m), myelin figures (mf), nucleus (n), plastid (p), primary cell wall (pcw), ribosomes (r), small vacuoles (sv), vacuole (v). Bars: $\mathbf{A}=5 \mu \mathrm{m}, \mathbf{B}, \mathbf{D}, \mathbf{E}=1 \mu \mathrm{m}, \mathbf{C}=500 \mathrm{~nm} . \mathbf{F}=2 \mu \mathrm{m}$. 


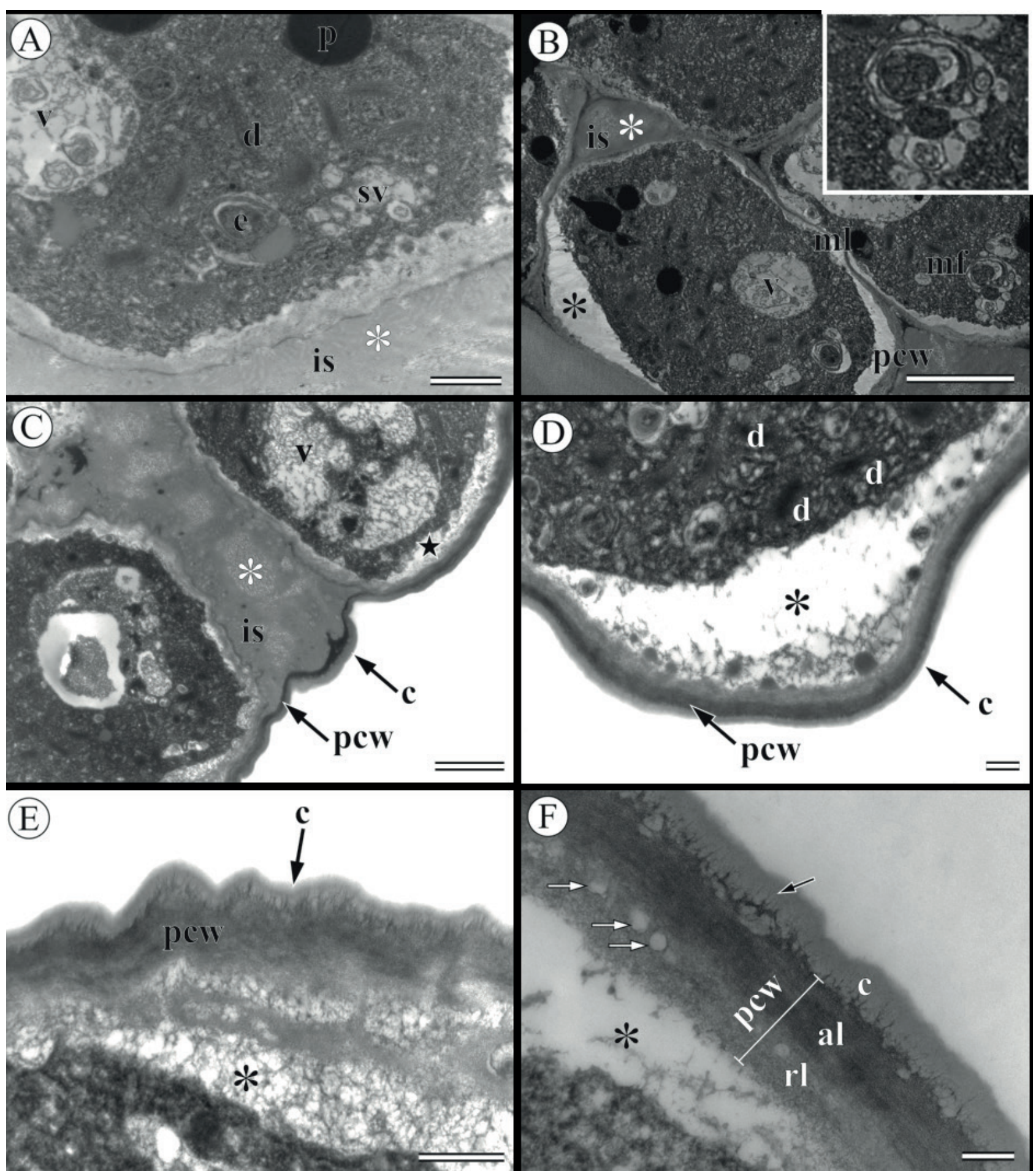

Figure 4. Ultrastructural evidence of the exudation mechanism of the secretion produced by colleters of Calolisianthus speciosus. A: Small vacuoles associated with TGN and vacuoles containing myelin figures. Note endosome formation in the cytoplasm. B: Cells adjacent to the central portion of the secretory head with intercellular spaces (white asterisk) and periplasmic space (black asterisk) with secretion. Myelin figures were observed in cytoplasm (detail). C: Detail of the superficial cells of the secretory head evidencing intercellular space filled with amorphous secretion (white asterisk). D: Detail of the periplasmic space formed by the accumulation of secretion (black asterisk) between the plasma membrane of a superficial cell and the wall covered by the cuticle. E: Detail of the content accumulated in the periplasmic space (black asterisk) between the outer wall layers and the cuticle proper. F: Detail of the outer wall layers, note the deformation of the polysaccharide wall (white arrow) and cuticular channels (black arrow). arborescent layer (al), cuticle (c), dictyosome (d), endosome (e), intercellular space (is), myelin figures (mf), middle lamella (ml), primary cell wall (pcw), plastid (p), reticulated layer (rl), small vacuoles (sv), vacuole (v). Bars: A, E=1 $\mu \mathrm{m}, \mathrm{B}=5 \mu \mathrm{m}, \mathrm{C}=500 \mu \mathrm{m}, \mathrm{D}=200 \mu \mathrm{m}, \mathrm{F}=2 \mu \mathrm{m}$. 
cuticle (Fig. 4C-F), which keeps this layer continuous and the surface intact, even during the secretory process. Three layers were recognized in the outer wall of the superficial cells of the secretory head: the primary wall rich in polysaccharides, the cuticle layer (subdivided into a reticulated and arborescent layer) and the cuticle proper (Figure 4E, F). Secretions accumulated in the periplasmic space and in the intercellular spaces cross the cuticle to reach the external environment (Fig. 4E, F). Changes to both the outer periclinal wall and the cuticle layers were observed (Fig. 4F). The pectic layer of the wall appears to be digested while the cellulosic portion assumes a lamellar appearance (Fig. 4F). In the periplasmatic space, both granular and homogeneous material were observed in contact with outer wall of the superficial cells (Fig. 4D-F). A polysaccharide fibrillary network forming microchannels was noted in the cuticle proper, immediately below of which small vesicles are evident (Fig. 4F).

\section{Discussion}

The leaf and sepal colleters of $C$. speciosus are anatomically similar. Both are non-vascularized and formed by a secretory multicellular head with large intercellular spaces wherein secretion accumulates before being exuded. Although colleters are mentioned as a common feature among species of Gentianaceae (Judd et al. 2007) and typical for the genus Calolisianthus (Struwe et al. 2002), there are few studies that have characterized them anatomically. Structures similar to those described herein for $C$. speciosus were reported for the leaves, at stem insertion region of $C$. amplissimus and C. pendulus, as well as in the calyx of $C$. speciosus (Delgado 2008) and C. peduculatus (Dalvi et al. 2020), all species from the tropical region (Struwe et al. 2002).

Morphologically distinct types of colleters have been reported in the literature (Lersten 2008; Thomas 1991; Silva et al. 2017), and the distribution, typology and the presence of calcium oxalate crystals are characters frequently used in taxonomic (Lersten 1974; Coutinho et al. 2015; Lopes-Mattos et al. 2015) and evolutionary approaches (Vitarelli et al. 2015; Judkevich et al. 2017). The standard colleter type, formed by a non-secretory parenchyma axis covered by palisade secretory epidermis (Fahn 1988; Thomas 1991), is the most common and has been recorded in several unrelated families such as Euphorbiaceae (Machado et al. 2015; Vitarelli et al. 2015; Feio et al. 2016), Rubiaceae (Lopes-Mattos et al. 2015; Judkevich et al. 2017) and Salicaceae (Fernandes et al. 2016; Faria et al. 2019), but only for Macrocarpea obtusifolia in Gentianaceae (Dalvi et al. 2014a). Colleters with large intercellular spaces that accumulate secretion, as reported here for C. speciosus, seem to be common for species of Gentianaceae both in the Neotropics (Delgado et al. 2011; Dalvi et al. 2020) and in the temperate region (Renobales et al. 2001).
Colleters of $C$. speciosus originate exclusively from protoderm, which allows them to be interpreted as of the trichome type, as described for Gentiana and allied genera of Gentianaceae from the temperate region (Renobales et al. 2001) and C. pedunculatus from the Neotropical region (Dalvi et al. 2020). Although Macrocarpea obtusifolia (Gentianaceae) possesses the standard type, its colleters are also exclusively derived from protoderm (Dalvi et al. 2014a; 2020). Large intercellular spaces are formed at the final development stages of colleters of $C$. speciosus, which is the beginning of the secretory phase. No evidence of cellular lysis was observed in any development stage of the colleters of $C$. speciosus, which is strong evidence for a schizogenous origin of the large intercellular spaces filled with secretion. Uncommon cavitated secretory trichomes were described for Fabaceae (Marinho et al. 2016) and Rutaceae (Zhou et al. 2012), but the secretory hollow head where secretion is accumulated is developed by cell lysis in a typical process of programmed cell death.

Dissolution of the middle lamella during the secretory phase, as observed herein, has been reported for colleters in different botanical families (Ben-Arie et al. 1979; Appezzatoda-Glória \& Estelita 2000; Machado et al. 2012; Fernandes et al. 2017; Almeida \& Paiva 2019). However, secretion is accumulated only in intercellular spaces developed between the palisade secretory cells of standard colleters (Paiva 2009; Mercadante-Simões \& Paiva 2013; Machado et al. 2015; Fernandes et al. 2017). The secretion process is quite different in $C$. speciosus since the external periclinal wall and cuticle are preserved, which allows these cells to remain attached to each other while the internal cells are separated from each other by large intercellular spaces where secretion that passes through the wall is accumulated. These intercellular spaces are apparently formed by schizogeny.

The leaf and sepal colleters of $C$. speciosus develop early and produce predominantly polysaccharide secretion that covers the apical meristems and floral buds. Polysaccharides bear hygroscopic properties, which is in agreement with the function assigned for colleter exudate that protects young leaf and floral buds against desiccation and attack of pathogenic microorganisms and small phytophagous plants (Silva et al. 2012; Mayer et al. 2013; Miguel et al. 2017; Ribeiro et al. 2017). Additionally, due to its sticky consistency, mucilage adheres small phytophages and herbivorous, thus protecting leaves and flowers at the beginning of their development (Machado et al. 2015), as well as lubricating the surface during organ expansion (Thomas 1991). Starch was detected only in leaf colleters collected during the floral phenophase. The flower represents a strong drain to reserved starch during this phenophase.

Proteins detected in the sepal and leaf colleters of $C$. speciosus are also common components produced by colleters in different species of unrelated families (Machado et al. 2014; Dalvi et al. 2014a; Judkevich et al. 2017). Studies have demonstrated that such proteins have enzymatic activity, 
which would further act in defense against the development of pathogenic microorganisms (Maffei 2010; Chern et al. 2013; Miguel et al. 2006). The presence of phenolic compounds may be related to colleter senescence, as reported elsewhere in the literature (Souza 2014; Fernandes et al. 2017). For C. speciosus, phenolic compounds were detected only in colleters of sepals, which suggests that the collections did not cover the entire senescent phase of the leaf colleters.

The ultrastructural characteristics of the secretory cells observed here for $C$. speciosus are in agreement with the results of the histochemical tests of sepal and leaf colleters. Numerous mitochondria, dictyosomes and GER are involved with the synthesis and delivery of proteins and polysaccharides in plant cells (Kristen \& Lockhausen 1985; Wayne 2009; Buchannan et al. 2015), which are also common organelles in the cytoplasm of colleters (Zhou et al. 2012; Marinho et al. 2016; Fernandes et al. 2017; Almeida \& Paiva 2019). The secretory pathway of plants has been the subject of research for decades, especially concerning vesicle trafficking mechanisms involving the formation of lytic and storage vacuoles (Vitale \& Hinz 2005). Cui et al. (2019) presented a model for vacuole biogenesis based on whole-cell electron tomography analysis. Multivesicular bodies (MVBs) are smaller than small vacuoles (SVs) and derive from the TGN, while $S V$ s are larger and originate from GER, yet both organelles are independent and bear intraluminal vesicles (ILV). Our ultrastructural images produced similar findings, since the largest vesicles close to GER may correspond to SVs, while the small vesicles associated with the TGN would correspond to MVBs. According to the model proposed by Cui et al. (2019), the large vacuoles are derived from the merger of an SV with an SV or with a MVB, which we also observed in the secretory phase of the colleters of $C$. speciosus.

Secretion produced and accumulated in a vacuole is released to the periplasmatic space by the merger between tonoplast and the plasma membrane in secretory cells of colleters of $C$. speciosus. This mechanism can be explained by the model proposed by Paiva (2016), where after the merger, the accumulation of secretion in the periplasmatic spaces causes pressure in the cytoplasm, resulting in secretion passage through the cell wall. The fusion of the large vacuole with the plasma membrane increases the total surface area of the plasma membrane and promotes endocytic vesicle formation to maintain the plasma membrane. Our finding is in accordance with the functional role of endosomes in plants, since they are responsible for the uptake of extracellular materials in the periplasmatic space and transferring it to the cytoplasm (Meckel et al. 2004), as well recycling and maintaining plasma membrane receptors (Altenbach \& Robatzek 2007). Myelin figures are formed inside vacuoles, as a feature of the process of exocytosis, as a result of incorporating a membrane of a vesicle into the plasma membrane (Raatikainen et al. 1992). Similar results were reported for the secretory process in Pterodon pubescens
(Benth.) Benth. (Rodrigues \& Machado 2012) and Dahlstedtia pentaphylla (Taub.) Burkart (Teixeira \& Rocha 2009).

Revision based on three-dimensional electron tomography (Contento \& Bassham 2012), showed that there are two endosomal compartments in plant cells - an early endosome (or vesicle associated with the TGN) and a late endosome (or MVB, or prevacuolar compartment). According to the proposed model, TGN matures into an MVB, which then fuses with the vacuole to release its contents, events similar to those showed in the secretory phase of the colleters of $C$. speciosus. The presence of leucoplasts, similar to those observed in the secretory cells of C. speciosus, was reported for colleters of Casearia sylvestris SW. (Fernandes et al. 2017). This type of plastid is involved with the terpenoid biosynthesis pathway (Fahn 1979; Ascensão \& Pais 1998; Buchanan et al. 2015). Tests for lipids and terpene compounds were negative for $C$. sylvestris, which the authors argue as being due to an insufficient amount of these substances for detection, which may be the case for $C$. speciosus as well.

The process of colleter exudation through cuticle rupture had been described in general in the literature (Almeida \& Paiva 2019; Pinheiro et al. 2019). However, the mechanism of colleter exudation in $C$. speciosus occurs through microchannels in the cuticle formed by a polysaccharide fibrillary network, which permits the cuticle proper to remain intact during the exudation process. The same occurs with colleters of the savanna species Tocoyena Formosa (Cham. \& Schltdl.) K. Schum. and Coccocypselum lanceolatum (Ruiz \& Pav.) Pers. (Tresmondi et al. 2017), and the Atlantic Forest species Bathysa nicholsonii K. Schum. (Miguel et al. 2017). Such microchannels are known to occur in secretory cells of other glandular structures, such as osmophores (Pridgeon \& Estern 1983; Stpiczyńska 2001) and nectaries (Passini \& Nepi 2007). The accumulation of secretion in intercellular spaces of colleters of $C$. speciosus would move the secretion towards the cuticle of superficial cells in a manner similar to that reported for colleters of $C$. sylvestris. (Fernandes et al. 2017). The cuticle represents the last barrier for secretion exudation. The deformations observed in the outer wall layers and the cuticle microchannels of the colleters of $C$. speciosus are consistent with the exudation model proposed by Miguel et al. (2017) for colleters of species of Rubiaceae. As also observed by these authors, we observed three layers on the outer face of the secretory epidermal cells of colleters of $C$. speciosus: a basal polysaccharide rich layer, a cuticle membrane (subdivided into arborescent and reticulated layers) and a thin cuticle proper. Due to the accumulation of mucilage, the polysaccharide-rich layer undergoes deformation and the secretion is driven through the reticulate and arborescent layer. Therefore, exudation occurs due to pressure from the secretion accumulated in the intercellular space allowing it to cross the wall. The laminar constitution of the outer wall allows exudation to the outside through tiny channels of the cuticle. 


\section{Analu Zanotti, Valéria Ferreira Fernandes, Aristéa Alves Azevedo and Renata Maria Strozi Alves Meira}

\section{Acknowledgements}

We thank Coordenação de Aperfeiçoamento de Pessoal de Nivel Superior (CAPES, Finance Code 001) and Fundação de Amparo à Pesquisa do Estado de Minas Gerais (FAPEMIG) for funding the research. Analu Zanotti thanks CAPES for granting her a Ph.D scholarship; Renata Meira (DEB \#306740/2019-2) thanks CNPq for her productivity grants and Centro de Microscopia Eletrônica da Universidade Estadual de Santa Cruz (UESC) and Centro de Microscopia e Microanálise da Universidade Federal de Viçosa (UFV) for the assistance.

\section{References}

Almeida AL, Paiva EAS. 2019. Colleters in Mabea fistulifera Mart. (Euphorbiaceae): Anatomy and biology of the secretory process. Flora 258: 151439. doi: 10.1016/j.flora.2019.151439

Altenbach D, Robatzek S. 2007. Pattern recognition receptors: from the cell surface to intracellular dynamics. Molecular Plant-microbe Interactions 20: 1031-1039.

Appezzato-da-Glória B, Estelita ME. 2000. Development, structure and distribution of colleters in Mandevilla illustris and M. velutina (Apocynaceae). Brazilian Journal of Botany 23: 113-120.

Ascensão L, Pais MS. 1998. The leaf capitate trichomes of Leonotis leonurus: histochemistry, ultrastructure and secretion. Annals of Botany 81: 263-271.

Ben-Arie R, Kislev N, Frenkel C. 1979. Ultrastructural changes in the cell walls of ripening apple and pear fruit. Plant Physiology 64: 197-202.

Brillouet J-C, Romieu C, Schoefs B, et al. 2013. The tannosome is an organelle forming condensed tannins in the chlorophyllous organs of Tracheophyta. Annals of Botany 112: 1003-1014.

Buchanan BB, Gruissem W, Jones RL. 2015. Biochemistry and Molecular Biology of Plants. 2nd ed. West Sussex, Willey Blackwell.

Calió MF. 2009. Sistemática de Helieae Gilg (Gentianaceae). PhD Thesis. Universidade de São Paulo, São Paulo.

Calió MF, Lepis KB, Pirani JR, Struwe L. 2017. Phylogeny of Helieae (Gentianaceae): Resolving taxonomic chaos in a Neotropical clade. Molecular Phylogenetics and Evolution 106: 192-208.

Chern LY, Shukor MY, Muse R. 2013. Monoterpenes in plants - a mini review. Asian Journal of Plant Biology 1: 15-19.

Contento AL, Bassham DC. 2012. Structure and function of endosomes in plant cells. Journal of Cell Science 125: 3511-3518.

Coutinho ÍAC, Francino DMT, Meira RMSA. 2015. New records of colleters in Chamaecrista (Leguminosae, Caesalpinioideae SL): structural diversity, secretion, functional role, and taxonomic importance. International Journal of Plant Sciences 176: 72-85.

Cui Y, Cao W, He Y, Zhao Q, Wakazaki M, Zhuang X, Wong HY. 2019. A whole-cell electron tomography model of vacuole biogenesis in Arabidopsis root cells. Nature Plants 5: 95-105.

Dalvi VC, Cardinelli LS, Meira RMSA, Azevedo AA. 2014a. Foliar colleters in Macrocarpaea obtusifolia (Gentianaceae): anatomy, ontogeny, and secretion. Botany 92: 59-67.

Dalvi VC, Meira RMSA, Francino DMT, Silva LC, Azevedo AA. 2014b. Anatomical characteristics as taxonomic tools for the species of Curtia and Hockinia (Saccifolieae-Gentianaceae Juss.). Plant Systematics and Evolution 300: 99-112.

Dalvi VC, De Faria GS, Azevedo AA. 2020. Calycinal secretory structures in Calolisianthus pedunculatus (Cham. \& Schltdl) Gilg (Gentianaceae): anatomy, histochemistry, and functional aspects. Protoplasma 1: 1-10.

Delgado MN. 2008. Caracterização morfoanatômica de espécies de Gentianaceae ocorrentes em áreas de cerrado e de campo rupestre em Minas Gerais. MSc Thesis. Universidade Federal de Viçosa, Viçosa.
Delgado MN, Azevedo AA, Silva LC, Valente GE, Kasuya MCM. 2011. Comparative anatomy of Calolisianthus species (Gentianaceae-Helieae) from Brazil: taxonomic aspects. Edinburgh Journal of Botany 68: 139-155.

Fahn A. 1988. Secretory tissues in vascular plants. New Phytologist 108: 229-257.

Fahn A. 1979. Secretory tissues in plants. London, Academic Press.

Faria DNS, Fernandes VF, Marquete R, Meira RMSA. 2019. Morphology, anatomy and exudates of stipular colleters in Casearia Jacq. (Salicaceae) across two tropical plant communities. International Journal of Plant Sciences 180: 141-152.

Feio AC, Riina R, Meira RMSA. 2016. Secretory structures in leaves and flowers of two dragon's blood Croton (Euphorbiaceae): new evidence and interpretations. International Journal of Plant Sciences 177: 511-522.

Fernandes VF, Thadeo M, Dalvi VC, Marquete R, Meira RMSA. 2016. Colleters in Casearia (Salicaceae): a new interpretation for the theoid teeth. Botanical Journal of the Linnean Society 181: 682-691.

Fernandes VF, Thadeo M, Dalvi VC, Meira RMSA. 2017. Secretory structures in Casearia sylvestris Sw. (Salicaceae): diversity, mechanisms of secretion, and exudate complexity. International Journal of Plant Sciences 178: 288-301.

Fisher DB. 1968. Protein staining of ribboned epon sections for light microscopy. Histochemie 16: 92-96.

González AM. 1998. Colleters in Turnera and Piriqueta (Turneraceae). Botanical Journal of the Linnean Society 128: 215-228.

Huang SS, Kirchoff BK, Liao JP. 2008. The capitate and peltate glandular trichomes of Lavandula pinnata L. (Lamiaceae): histochemistry, ultrastructure, and secretion. The Journal of the Torrey Botanical Society 135: 155-167.

Johansen DA. 1940. Plant microtechnique. New York, McGraw-Hill.

Judd WS, Campbell CS, Kellogg EA, Stevens PF, Donoghue MJ. 2007. Plant systematics: a phylogenetic approach vegetal. 3nd. ed. Sunderland, Sinauer Associates Inc.

Judkevich MD, Salas RM, Gonzalez AM. 2017. Colleters in American Spermacoceae Genera (Rubiaceae): Morphoanatomical and Evolutionary Aspects. International Journal of Plant Sciences 178: 378-397.

Kristen U, Lockhausen J. 1985. The leaf glands of Veronica beccabunga L.: ultrastructure and a possible pathway of secretion. Israel Journal of Botany 34: 147-156.

Lersten NR. 1974. Morphology and distribution of colleters and crystals in relation to the taxonomy and bacterial leaf nodule symbiosis of Psychotria (Rubiaceae). American Journal of Botany 61: 973-981.

Lersten NR. 2008. Trichome forms in Ardisia (Myrsinaceae) in relation to the bacterial leaf nodule symbiosis. Botanical Journal of the Linnean Society 75: 229-244.

Lillie RD. 1965. Histopathologic technic and practical histochemistry, 3rd. ed. New York, McGrawHill.

Lopes-Mattos KLB, Otuki SAP, Azevedo AA, Pereira ZV, Meira RMSA. 2015. Colleters in 10 species belonging to three tribes of Rubiaceae: morphoanatomical diversity and potential as useful characters for taxonomy. Botany 93: 425-434.

Lüttge U, Schnepf E. 1976. Elimination processes by glands. Organic substances. In: Lüttge U, Pitman MG. ed. Transport in plants II, Encyclopedia of Plant Physiology. Vol. 2B. New York, Springer.

Machado SR, Barreiro DP, Rocha JF, Rodrigues TM. 2012. Dendroid colleters on vegetative and reproductive apices in Alibertia sessilis (Rubiaceae) differ in ultrastructure and secretion. Flora-Morphology, Distribution, Functional Ecology of Plants 207: 868-877.

Machado SR, Teixeira SDP, Rodrigues TM. 2014. Bacterial leaf glands in Styrax camporum (Styracaceae): first report for the family. Botany 92: 403-411.

Machado SR, Paleari LM, Paiva EAS, Rodrigues TM. 2015. Colleters on the inflorescence axis of Croton glandulosus (Euphorbiaceae): Structural and functional characterization. International Journal of Plant Sciences 176: 86-93.

Maffei ME. 2010. Sites of synthesis, biochemistry and functional role of plant volatiles. South African Journal of Botany 76: 612-631. 
Marinho CR, Oliveira RB, Teixeira SP. 2016. The uncommon cavitated secretory trichomes in Bauhinia s.s. (Fabaceae): the same roles in different organs. Botanical Journal of the Linnean Society 180: 104-122.

Martins FM. 2012. Leaf and calycine colleters in Odontadenia lutea (Apocynaceae - Apocynoideae - Odontadenieae): their structure and histochemistry. Brazilian Journal of Botany 35: 59-69.

Mayer JLS, Carmello-Guerreiro SM, Mazzafera P. 2013. A functional role for the colleters of coffee flowers. Annals of Botany 5: 1-13.

McManus JFA. 1948. Histological and histochemical uses of periodic acid. Stain Technology 23: 99-108.

Meckel T, Hurst AC, Thiel G, Homann U. 2004. Endocytosis against high turgor: intact guard cells of Vicia faba constitutively endocytose fluorescently labelled plasma membrane and GFP-tagged K+-channel KAT1. The Plant Journal 39: 182-193.

Mercadante-Simões MO, Paiva EAS. 2013. Leaf colleters in Tontelea micrantha (Celastraceae, Salacioideae): Ecological, morphological and structural aspects. Comptes Rendus Biologies 336: 400-406.

Miguel EC, Gomes VM, Oliveira MA, Cunha M. 2006. Colleters in Bathysa nicholsonii K. Schum. (Rubiaceae): ultrastructure, secretion protein composition, and antifungal activity. Plant Biology 8: 715-722.

Miguel EDC, Pireda S, Barros CF, et al. 2017. Outer cell wall structure and the secretion mechanism of colleters of Bathysa nicholsonii K. Schum. (Rubiaceae). Acta Botanica Brasilica 31: 411-219.

O’Brien TP, Feder N, McCully ME. 1964. Polychromatic staining of plant cell walls by toluidine blue O. Protoplasma 59: 368-373.

O’Brien TP, McCully M E. 1981. The study of plant structure principles and selected methods. Melbourne, Termarcarphi Pty.

Paiva EAS. 2009. Occurrence, structure and functional aspects of the colleters of Copaifera langsdorffii Desf. (Fabaceae, Caesalpinioideae). Comptes Rendus Biologies 332: 1078-1084.

Paiva EAS, Machado SR. 2006a. Colleters in Caryocar brasiliense (Caryocaraceae): ontogenesis, ultrastructure and secretion. Brazilian Journal of Biology 66: 301-308.

Paiva EAS. 2016. How do secretory products cross the plant cell wall to be released? A new hypothesis involving cyclic mechanical actions of the protoplast. Annals of Botany 117: 533-540.

Paiva EAS, Machado SR. 2006b. Ontogenesis, structure and ultrastructure of Hymenaea stigonocarpa (Fabaceae: Caesalpinioideae) colleters. Revista de Biología Tropical 54: 943-950.

Passini E, Nepi M. 2007. Nectar production and presentation. In: Nicolson SW, Nepi M, Passini E. eds. Nectaries and Nectar. New York, Springer.

Pearse AGE. 1972. Histochemistry: theoretical and applied. 3rd.edn. Baltimore, Williams \& Wilkins.

Pinheiro SKP, Teófilo FBS, Lima AKM, Cordoba BV, Miguel TBAR, Miguel EC. 2019. Ontogenesis and secretion mechanism of Morinda citrifolia L. (Rubiaceae) colleters. South African Journal of Botany 121: 26-33.

Pridgeon AM, Stern WI. 1983. Ultrastructure of osmophores in Restrepia (Orchidaceae). American Journal of Botany 70: 1233-1243.

Raatikainen OJ, Taipale HT, Pelttari A, Lapinjoki P. 1992. An electron microscope study of resin production and secretion by the glands of seedlings of Betula pendula Roth. New Phytologist 122: 537-543.

Renobales G, De Diego E, Urcelay B, López-Quintana A. 2001. Secretory hairs in Gentiana and allied genera (Gentianaceae: subtribe Gentianinae) from the Iberian Peninsula. Botanical Journal of the Linnean Society 136: 119-129.

Reynolds ES. 1963. The use of lead citrate at high $\mathrm{pH}$ as an electron opaque staining in electron microscopy. The Journal of Cell Biology 17: 208-212.
Ribeiro JF, Almeida SP, Sano SM. 2008. Cerrado: ecologia e flora. Brasília, Embrapa Informação Tecnológica.

Ribeiro JC, Ferreira MJP, Demarco D. 2017. Colleters in Asclepiadoideae (Apocynaceae): protection of meristems against desiccation and new functions assigned. International Journal of Plant Sciences 178: 465-477.

Rodrigues TM, Machado SR. 2012. Oil glands in Pterodon pubescens Benth. (Leguminosae-Papilionoideae): distribution, structure, and secretion mechanisms. International Journal of Plant Sciences 173: 984-992.

Silva CJ, Barbosa LCA, Marques AE, Baracat-Pereira MC, Pinheiro AL, Meira RMSA. 2012. Anatomical characterization of the foliar colleters in Myrtoideae (Myrtaceae). Australian Journal of Botany 60: 707-717.

Silva MDS, Coutinho ÍAC, Araújo MN, Meira RMSA. 2017. Colleters in Chamaecrista (L.) Moench sect. Chamaecrista and sect. Caliciopsis (Leguminosae-Caesalpinioideae): anatomy and taxonomic implications. Acta Botanica Brasilica 31: 382-391.

Simões AO, Kinoshita LS. 2002. The Apocynaceae s. str. of the Carrancas region, Minas Gerais, Brazil. Darwiniana 40:127-169.

Souza LM. 2014. Estruturas secretoras em espécies de leguminosas da subtribo Cassiinae (Fabaceae, Caesalpinioideae, Cassieae). PhD Thesis, Universidade Federal de Minas Gerais, Belo Horizonte.

Stpiczyńska M. 2001. Osmophores of the fragrant orchid Gymnadenia conopsea L. (Orchidaceae). Acta Societatis Botanicorum Poloniae 70: 91-96.

Struwe L, Kadereit J, Klackenberg J, et al. 2002. Systematics, character evolution and biogeography of Gentianaceae, including a 15 new tribal and subtribal classification. In: Struwe L, Albert VA. (eds.) Gentianaceae - Systematics and Natural History. Cambridge, Cambridge University Press.

Teixeira SDP, Rocha JF. 2009. Oil glands in the Neotropical genus Dahlstedtia Malme (Leguminosae, Papilionoideae, Millettieae). Brazilian Journal of Botany 32: 57-64.

Thiers B (continuously updated). Index Herbariorum: a global directory of public herbaria and associated staff. New York Botanical Garden's Virtual Herbarium. http://sweetgum.nybg. org/ih/. 08 Sep. 2020.

Thomas V. 1991. Structural, functional and phylogenetic aspects of the colleter. Annals of Botany 68: 287-305.

Tresmondi F, Nogueira A, Guimarães E, Machado SR. 2015. Morphology, secretion composition, and ecological aspects of stipular colleters in Rubiaceae species from tropical forest and savanna. The Science of Nature 102: 73. doi: 10.1007/s00114-015-1320-5

Tresmondi F, Canaveze Y, Guimarães E, Machado SR. 2017. Colleters in Rubiaceae from forest and savanna: the link between secretion and environment. The Science of Nature 104: 17. doi:10.1007/s00114017-1444-x

Vitale A, Hinz G. 2005. Sorting of proteins to storage vacuoles: how many mechanisms? Trends in plant science 10: 316-323.

Vitarelli NC, Riina R, Caruzo MB, Cordeiro I, Aguilar J-F, Meira RMSA. 2015. Foliar secretory structures in Crotoneae (Euphorbiaceae): diversity, structure, and evolutionary significance. American Journal of Botany 102: 1-15.

Wayne RO. 2009. Plant cell biology: from astronomy to zoology. San Diego, Academic Press.

Zhou YF, Shi HY, Liu WZ. 2012. Ontogenesis of trichome-like cavities in Dictamnus dasycarpus. Flora-Morphology, Distribution, Functional Ecology of Plants 207: 63-73. 